\title{
Ways to Improve the Teaching Effectiveness of Ideological and Political Course in Colleges and Universities in China
}

\author{
Minghui Chen \\ Yunnan Normal University \\ Kunming, China 650000
}

\begin{abstract}
To implement the spirits of the national conference on ideological and political work in colleges and universities put forward by General Secretary Xi Jinping, we should play the role of ideological and political course as main channel well. We should improve the effectiveness of the ideological and political course, find the restraining factors and put forward resolution to the problems. We should take the transformation of teaching ideas as guide, full grasp of teaching content as foundation, innovation of teaching modes as premise and reform of examination way as guarantee and the optimization of personal quality as key to effectively improve the teaching effectiveness of ideological and political course in colleges and universities.
\end{abstract}

Keywords-ideological and political course; effectiveness; effective ways

\section{INTRODUCTION}

In the national conference of ideological and political work in colleges and universities, General Secretary Xi Jinping pointed out that we shall follow the law of ideological and political work, meet the challenges and accurately know the new situation. It is clearly that we should follow the objective law of ideological and political education, adhere to the moral education as the central link and carry out the ideological and political work throughout the entire process of education in order to achieve full education and all-round education. [1] The ideological and political course in colleges and universities is the main channel for college students to receive ideological and political education and an important way to help college students set up correct world outlook, outlook on life and values, so it plays a leading role in ideological and political education for college students. [2] We should grasp the law of ideological and political education and the growth law and success law of college students scientifically and find key factors that restrict the effectiveness of teaching and take corresponding ways to solve them in order to play this main channel well.

II. The IMPORTANT FACTORS AFFECTING THE TEACHING EFFECTIVENESS OF IDEOLOGICAL AND POLITICAL COURSES

There are many factors restricting the effectiveness of ideological and political course. But it mainly focuses on three aspects: course setting, teachers and educatee. They are mainly embodied in the following aspects.

\section{A. The Course Setting Is not Reasonable Enough, and "Teaching" and "Learning" Are Disjointed}

The poor teaching effect of ideological and political course is a common phenomenon in our colleges and universities, which is affected by its internal contradictions. First, it lies in the contradiction between the course content and teaching process. The ideological and political theory itself has characteristics of systematicness, abstractness and criticalness, which has a conflict between didacticism and politics in the teaching process. Second is the contradiction between theory shaping and practice examining. Students experience the transformation from practice-oriented teaching mode before entering college into the theory-shaped teaching mode in college. The theoretical education with practice can only get goal in mastering knowledge, and cannot fully achieve goals in training ability and quality. Third is the contradiction between course setting and examination way. Ideological and political course is an education from spiritual consciousness. It is a project building in one's heart. It is a long-term and hard task. However, real examination way and standard deform students' learning motivation and the original goal of ideological and political course.

\section{B. The Teachers Is not Qualified Enough, which Is the Key} Factor that Restricts the Effectiveness of Teaching

First, some political and ideological teachers are lack of political consciousness. They lack self-confidence and sense of pride. They fail to give full play to ideological and political course as the main position and main channel in ideological and political education. Second, the ideological and political course involves a wide range of content and involves a wide range of fields. It requires a solid academic foundation, a keen insight and a correct analysis of the hot and difficult political affairs. These requirements are often the short board of ideological and political teachers. Third, the teaching process is not targeted. Ideological and political teachers often use the theory of textbooks to contrast with reality, which make it lose persuasion. At the same time, they are not enough to combine students' characteristics and concerns. The single teaching method makes the teaching effect poor. It can be seen that the 
politics, enthusiasm, knowledge structure and professional level of ideological and political teachers mostly cannot meet the teaching requirements, resulting in an unsatisfactory teaching effect.

\section{The Characteristics of the Educatees Increase the Difficulty in the Improvement of the Teaching Effectiveness of Ideological and Political Course}

At present, the educatees in the ideological and political course are mainly the "post-90s" college students. They have distinct personality and diverse values, and are easy to accept new things. However, they lack discrimination on goodness and evil, and are susceptible to external environment. In general, they have several characteristics. First, they stress practicality. Affected by social environment, many college students are prone to pragmatism in learning. For example, if learning contents are not associated with future employment, their enthusiasm will be reduced. It results in that many college students take ideological and political courses in order to get scores or make foundation for their postgraduate study or civil servant examination. It greatly affects the effectiveness of ideological and political course. Second, they are passive. College students are independent in personality, advocating communication and negotiation. But in traditional teaching, students reject didactic and force-feeding teaching methods. Most college students are passive in the process of ideological and political learning. They only focus on knowledge itself, and do not pay attention to the cultivation of their own learning ability. They pay close attention to classroom teaching process, and ignore the organic combination of theory and practice, which is far from the goal of ideological and political education to internalize in one's heart and externalize in one's behavior. Third, they are afraid of difficulty. The ideological and political content involves deep theories, with strong practical relevance, so the course itself has higher requirements on students' basic quality and attention to the reality. But the "post-90s" students generally pay little attention to the situations of the world, our country and our party. They are indifferent to foreign and domestic hot affairs, so the teaching effect is poor.

\section{MEASURES AND SUGGeSTIONS TO IMPROVE THE EFFECTIVENESS OF IDEOLOGICAL AND POLITICAL COURSE}

The effectiveness of ideological and political teaching refers to the real effect in teaching. We should find the factors restricting the effectiveness of teaching and find out key problems and take effective measures to solve them.

\section{A. Take the Transformation of Teaching Idea as Guide and Set up a Correct Educational Concept}

Whether the teaching idea is correct or not has a direct influence on the realization of the effectiveness of the teaching. Ideological and political teachers should keep the idea of "educating people first and putting moral education first" in mind, which is the educational function and nature of college students' ideological and political education. In the teaching process, teachers should establish a "people-oriented" concept in teaching. First, carry out the idea of humanistic care. Teachers should put students first, respect students, understand students and care for students. Love them and help them. Teachers should help students improve their learning independence and self-awareness in practice, and often communicate with students and know their needs. Second, teachers should respect students' subjectivity and subjective consciousness and pay attention to their personal determination. Teachers should talk and discuss problems and exchange ideas with students equally and fully mobilize the enthusiasm and consciousness of students. Third, teachers should have the idea of "teaching students in accordance with their aptitude". Make different course design according to characteristics of educatee group. As for student majoring in science, teachers should pay more attention to explanation of basic knowledge and combination of real cases. As for students majoring in liberal arts, teachers should pay more attention to extension of knowledge and analysis of hot affairs, especially for students majoring in PE and arts. The teaching design should not be single and theoretical. Teachers should use diverse teaching methods in teaching.

\section{B. Take Full Grasp of Teaching Content as Foundation and Establish a Reasonable Teaching System}

The key to improving the effectiveness of the ideological and political course is to transform the teaching material system into a teaching system. It is necessary to highlight the transformation of the advantages of the teaching materials to the teaching advantages, and then improve the actual effect of teaching. How to realize the two transformations lies in the teacher's leading role. Teachers should set up a systematic idea, global concept and innovative idea. In the teaching process, teachers should take teaching material as foundation and follow the logical structure of teaching materials and the main content, highlight key points, grasp difficulties, analyze hotspots and set up a complete teaching system. It's important for teachers to understand students. Teachers should design teaching content according to reality of students and real problems of students and the affairs they concerned, and then clear up doubts for them. It's important to follow the situation. To keep pace with the times is the theoretical quality of Marxism. Teachers should always stand in the forefront of the development of the times, and design the teaching content. The teaching content should reflect theoretical innovation achievements of the party, the new national laws and regulations, hot issues and social concerns. It's fundamental to base on ourselves. Teachers should organize teaching content according to characteristics of students and their majors and specific situations of students in different majors. For example, teachers should associate with our education reality in teaching students in normal colleges and universities, impart the historical responsibilities as a normal college students, guide students to base ourselves on education cause, love occupation of teacher, make a model for others and make a contribution for our education cause.

\section{Take the Innovation of Teaching Mode as Premise and Explore Effective Teaching Methods}

The characteristic of teaching in colleges and universities is that "there are methods for teaching, but the methods are not fixed". So, it is important to "use appropriate methods". Teaching methods should be diverse and flexible. It requires 
teachers to have a high ability to use teaching materials, carefully research teaching content, actively explore diversified and effective teaching modes, and realize the positive interaction between "teaching" and "learning" and the organic combination of "output" and "input" and replace the instillation teaching mode into the elicitation teaching mode. It can truly reflect the dominant position of students and achieve the effectiveness of teaching. Specifically, the four aspects should be combined together. First, adhere to the combination of class teaching and after-class guidance. Teachers should use different teaching methods according to content of teaching material and educatee groups, and mainly teach key points and difficulties in class, and related hotspots and difficulties in reality. In addition, teachers should guide and organize students to read extension readings, arrange guidance platform and self-learning task, and advocate students to carry out practical study in social activities. Second, insist on the combination of practice and theory. Teachers should guide students to participate in social practice. In practice, students may truly understand knowledge in textbooks. Teachers can check students' ability in uniting knowing and doing by examination in practice, and taking it as main reference for final evaluation. Third, adhere to the combination of traditional teaching and modern teaching. Both traditional teaching methods and modern teaching means have advantages. They are complementary to each other. On one hand, teachers should use traditional teaching methods, such as, writing teaching plan, teaching program and teaching case, and using traditional teaching way. On the other hand, teachers should actively learn and explore modern teaching means and make full use of multi-media. It has many advantages, such as, rich and timely information resources. Make use of MOOC, flipped classroom and micro-class to make up the shortcomings of traditional teaching in lacking teaching hours and heavy task. The combination of online self-learning mode and traditional teaching makes the teaching process complete and perfect. Fourth, adhere to the combination of the dominant education and recessive education. It is very limited to only give ideological and political education in class. We can learn the concept of character education from the United States to integrate social resources and implement ideological and political education throughout the growth of college students horizontally and vertically, and truly achieve the effectiveness of ideological and political course.

\section{Take the Reform of Evaluation System as Guarantee and Establish a Reasonable Evaluation System}

The degree of realization of teaching effectiveness is directly related to evaluation of students. It is not objective to examine students' learning effect only with a paper and regular scores. The result cannot truly judge and weigh students' theoretical level and accomplishment, nor fully assess their ideological and political consciousness, value orientation and inner belief. From the perspective of "knowing, feeling, thinking and doing", teachers should examine and check students from many aspects and in various forms, and establish a long-term and effective mechanism to evaluate students comprehensively. Firstly, teachers should change evaluation concept. The traditional evaluation concept attaches importance to knowledge and theory assessment. It often ignores evaluation on students' inner acceptance and transformation of practice. Students often are simply excited for a while and numb for a lifetime, which reflects the failure of teaching. Teachers should pay attention to the combination of theoretical assessment and practical assessment, and guide students to transform their knowledge into their own ideas and good behavior through the practice. Secondly, teachers should refine the examination content, adhere to the combination of theoretical examination and practical assessment according to the characteristics of the course, combine the usual assessment with the final examination, combine self assessment with teacher assessment, and set up multi-level, multi-angle and allround assessment contents. Third, establish a long-term assessment mechanism for the integration of resources. For example, make use of student societies, counselors, parents and classmates to establish a moral education file for students. Check students' law-abiding behaviors, learning life and ideological and moral status, and examine students comprehensively and give students an objective, fair and reasonable evaluation.

\section{E. Take the Optimization of the Qualities of Teachers as Key and Build a Teacher Team with Both Morality and Skills}

Ideological and political teachers in colleges and universities are the propagators of Marx theory and the party's line, principles and policies. They are propagators of socialist ideology and spiritual civilization, and guiders of college students for their healthy growth. [2] Teachers should not only be master interpreter of ideological and political knowledge, but also should be a model for students. To become a master interpreter requires teachers to study diligently and grasp a solid theoretical foundation, expand the field of knowledge, enhance innovative thinking, strengthen professional knowledge, and improve teaching ability. It requires them to understand students, pay attention to their state of mind, care about their problems, care for their study and life from the needs of the students and organize teaching from students' actual situation. They should also integrate the spirit of scientific research into teaching concept, enrich teaching content with scientific fruits and change teaching means with scientific methods. They should transform scientific research resources into teaching platforms, and promote the positive interaction between scientific research and teaching. To become a model for students, teachers should first enhance their personal charm. In political ideology, moral quality and learning style, they should set an example, and give full play to the teacher's influence on students and influence and enhance their spiritual realm with their own personality. In addition, teachers should improve the level of morality and undertake the teaching with a high sense of political responsibility and sense of mission. They should educate and influence students with own words and behaviors, and become a guider of students in the healthy growth course.

\section{CONCLUSION}

In a word, we should follow the law of ideological and political education, follow the rule of teaching and education, and follow the growth and success law of college students in order to improve the effectiveness of ideological and political 
course in colleges and universities. Teachers should deeply understand and implement the spirits in the national conference on the ideological and political work in colleges and universities held by the Party Central Committee. We should find out key factors restraining the effectiveness of ideological and political course, grasp key problems and make corresponding measures to solve them in order to play the main-position and main-channel role of ideological and political course in ideological education from the aspects of course setting, teacher team and educatee. In this way we can play the guarantee function of ideological and political education in the cultivation of qualified socialist builders and successors and the realization of the great rejuvenation of the Chinese nation.

\section{REFERENCES}

[1] General Secretary Xi Jinping, at the National Conference on Ideological and Political Work in Colleges and Universities, stressed that the ideological and political work should run through the whole process of education and teaching, and create a new prospect for the development of our higher education. People's Daily, 2016-12-09 (1).

[2] The Opinion of the Central Committee of the Communist Party of China on Further Strengthening and Improving the Ideological and Political Education of College Students. People.cn, 2004-10-14. 